\title{
Nitrogenous metabolism in Thoroughbred and Arabian foals from birth to five months of age
}

[Metabolismo do nitrogênio em potros PSI e Árabe do nascimento aos cinco meses de idade]

\author{
G. Piccione, A. Costa, F. Fazio, F. Grasso, G. Caola \\ Faculty of Veterinary Medicine - University of Messina \\ Polo Universitario dell'Annunziata \\ 98168 Messina, Italy
}

\begin{abstract}
The maturation of nitrogen metabolism was studied in six Thoroughbred and six Arabian foals. Rectal temperature, heart and respiratory rates and serum concentration of several hematochemical parameters (total protein, urea, uric acid, creatinine, and albumine) were monitored from birth to 5 months of age. In both breeds, all the parameters except albumine showed significant differences over time $(\mathrm{P}<0.05)$. The two breeds did not differ from each other at any time point. Statistically significant decreases in urea and creatinine concentrations were related to the growth needs of foals during this critical period of development.
\end{abstract}

Keywords: foal, nitrogenous metabolism, physiological parameters, growth

\section{RESUMO}

A maturação do metabolismo do nitrogênio foi estudada em seis potros da raça Puro-Sangue Inglês e seis da raça Árabe. A temperatura retal, batimento cardíaco e concentração sérica de várias características hematoquímicos (proteína total, uréia, ácido úrico, creatinina e albumina) foram investigadas do nascimento aos cinco meses de idade. Em ambas as raças, todas as características, exceto a albumina, mostraram diferenças significativas ao longo da maturação $(P<0,05)$. As duas raças não diferiram uma da outra durante os periodos de vida equivalentes. Reduções significativas das concentrações de uréia e creatinina mostraram as necessidades de crescimento dos potros durante esse período crítico de desenvolvimento.

Palavras-chave: potro, metabolismo do nitrogênio, características fisiológicas, crescimento

\section{INTRODUCTION}

Several studies on the assessment of functional abilities of the athlete horse using metabolic and hematological investigations have been carried out on adult subjects (Judson et al., 1983; Caola, 1986; Caola and Balbo, 1987; Greppi and Serrantoni, 1993; Aguera et al., 1995; Evans et al., 2002).
Normal values for adult horses are usually reported on veterinary medicine text books. Regarding foals, with the exception of some studies on metabolic profile (Sato et al., 1978) and blood parameters (Jeffcott et al., 1982; Bauer et al., 1984; Harvey et al., 1984), data from literature are scarce and not univocal.

Recebido em 1 de dezembro de 2004

Aceito em 10 de maio de 2006

E-mail: giuseppe.piccione@unime.it 
Muscular development occurs during the first year of life in the horse (Martin-Rosset et al., 1983). Muscular growing is the basis of athletic performance in the adult horse and it would be useful to determine serum levels of some metabolites mainly involved in muscular activity. Time from birth to $150^{\text {th }}$ day of life is a very critical period for foals, because of the significant changes which occur in growing organism. So, this study is aimed at understanding the metabolic processes which characterize the foal growth, in particular from birth to the fifth month of life, by examining the pattern of some physiological and hematological parameters, in order to obtain standard values for nitrogenous metabolism (total protein, urea, uric acid, creatinine, albumine) and some physiological parameters (rectal temperature, heart and respiratory rates).

\section{MATERIALS AND METHODS}

Six Thoroughbred and six Arabian clinically healthy female foals were used for this study. Foals from these two breeds are naturally inclined to physical activity. Foals were fed a commercial creep food, fortified with vitamins and minerals, which ensure the recommended percentage of total protein $(18 \%)$, calcium $(0.9 \%)$ and phosphorus $(0.6 \%)$. At 08.00 AM, rectal temperature, heart and respiratory rates were recorded from all foals. Blood samples were collected through jugular venipuncture, using vacutainer tubes ${ }^{1}$ with no additive. Recordings and collections were done on the day after birth and every 30 days until the fifth month of life, with a simultaneous monitoring system ${ }^{2}$. Blood samples were clotted at room temperature for $1 \mathrm{~h}$ and centrifuged at 2,000rpm for 20min; sera were then stored at $-20^{\circ} \mathrm{C}$. By means of a spectrophotometer ${ }^{3}$ serum concentrations of the following hematochemical parameters were analyzed as nitrogenous metabolism index: total proteins, with a biuret (end-point) colorimetric method (Code 90009051) ${ }^{4}$; urea, with an UV kinetic (fixed time) enzymatic method (Code $90005027)^{4}$; uric acid, with an enzymatic (endpoint) colorimetric method (Code 90001005$)^{4}$; creatinine, with a kinetic (fixed time) colorimetric method (Code 90006021) ${ }^{4}$ and albumine, with a BCG (end-point) colorimetric method (Code 90003401) ${ }^{4}$. To compare overall parameters studied on the different breeds at different times, two-way repeated measures analysis of variance (ANOVA) was used, being $\mathrm{P} \leq 0.05$ considered statistically significant. The Bonferroni significant difference test was applied for posthoc comparison.

\section{RESULTS AND DISCUSSION}

Tables 1 and 2 show average values of the haematochemical and physiological parameters, expressed in their conventional units of measurement with the related standard deviations and statistical significance observed in different experimental conditions in six Thoroughbred and Arabian foals.

By applying a two-way repeated measures analysis of variance, the following results were obtained: total protein (breed: $\mathrm{F}_{(1.50)}=0.64$, $\mathrm{P}=0.44$; time: $\quad \mathrm{F}_{(5.50)}=31.54, \quad \mathrm{P}<0.0001$; interaction: $\mathrm{F}_{(5,50)}=0.45, \mathrm{P}=0.80$ ); urea (breed: $\mathrm{F}_{(1.50)}=0.97, \quad \mathrm{P}=0.34$; time: $\quad \mathrm{F}_{(5.50)}=312.02$, $\mathrm{P}<0.0001$; interaction: $\left.\mathrm{F}_{(5.50)}=2.43, \mathrm{P}=0.04\right)$; uic acid (breed: $\mathrm{F}_{(1.50)}=0.02, \quad \mathrm{P}=0.87$; time: $\mathrm{F}_{(5.50)}=8.69, \mathrm{P}<0.0001$; interaction: $\mathrm{F}_{(5.50)}=0.17$, $\mathrm{P}=0.97$ ); creatinine (breed: $\mathrm{F}_{(1.50)}=0.001, \mathrm{P}=0.92$; time: $\quad \mathrm{F}_{(5.50)}=59.44, \quad \mathrm{P}<0.0001$; interaction: $\mathrm{F}_{(5.50)}=2.03, \quad \mathrm{P}=0.09$ ); $\quad$ albumine (breed: $\mathrm{F}_{(1.50)}=1.43, \mathrm{P}=0.25$, time: $\mathrm{F}_{(5.50)}=1.75, \mathrm{P}=0.14$; interaction: $\left.\quad \mathrm{F}_{(5.50)}=0.25, \quad \mathrm{P}=0.93\right)$; rectal temperature (breed: $\mathrm{F}_{(1.50)}=0.80, \mathrm{P}=0.39$; time: $\mathrm{F}_{(5.50)}=34.13, \mathrm{P}<0.0001$; interaction: $\mathrm{F}_{(5.50)}=0.39$, $\mathrm{P}=0.85$ ); heart rate (breed: $\mathrm{F}_{(1.50)}=0.51, \mathrm{P}=0.49$; time: $\quad \mathrm{F}_{(5.50)}=25.59, \quad \mathrm{P}<0.0001$; interaction: $\mathrm{F}_{(5.50)}=1.05, \mathrm{P}=0.40$ ); respiratory rate (breed: $\mathrm{F}_{(1.50)}=1.95, \quad \mathrm{P}=0.19 ; \quad$ time: $\quad \mathrm{F}_{(5.50)}=114.91$, $\mathrm{P}<0.0001$; interaction: $\left.\mathrm{F}_{(5.50)}=0.54, \mathrm{P}=0.74\right)$.

\footnotetext{
${ }^{1}$ Terumo Corporation, Japan.

${ }^{2}$ Argus TM-7, Schiller, Barr, Switzerland.

${ }^{3}$ Model DU-40, Beckman Instruments, Fullerton, CA.

${ }^{4}$ SEAC, Florence, Italy.
} 
Table 1. Average values of the haematochemical and physiological parameters, expressed in their conventional units of measurement with the related standard deviations and statistical significance observed in different experimental conditions in six Thoroughbred foals

\begin{tabular}{lcccccc}
\hline \multirow{2}{*}{ Parameters } & \multicolumn{5}{c}{ Experimental conditions } \\
\cline { 2 - 6 } & $1^{\text {st }}$ day & $30^{\text {th }}$ day & $60^{\text {th }}$ day & $90^{\text {th }}$ day & $120^{\text {th }}$ day & $150^{\text {th }}$ day \\
\hline Total protein $(\mathrm{g} / \mathrm{dl})$ & $5.47 \pm 0.31$ & $6.25 \pm 0.19^{*}$ & $6.12 \pm 0.29$ & $6.25 \pm 0.19^{*}$ & $6.72 \pm 0.23^{\bullet}$ & $6.17 \pm 0.19^{*} \mathbf{\Delta}$ \\
Urea $(\mathrm{mg} / \mathrm{dl})$ & $18.72 \pm 0.45$ & $15.10 \pm 0.62^{*}$ & $9.47 \pm 0.59^{*}$ & $12.98 \pm 0.70^{* \bullet}$ & $16.70 \pm 0.66^{\bullet}$ & $19.42 \pm 1.29^{\bullet \bullet \bullet}$ \\
Uric acid $(\mathrm{mmol} / \mathrm{l})$ & $0.46 \pm 0.08$ & $0.58 \pm 0.06^{*}$ & $0.50 \pm 0.06^{\bullet}$ & $0.51 \pm 0.05^{\bullet}$ & $0.49 \pm 0.06^{\bullet}$ & $0.50 \pm 0.03^{\bullet}$ \\
Creatinine $(\mathrm{mg} / \mathrm{dl})$ & $2.80 \pm 0.25$ & $1.48 \pm 0.32^{*}$ & $1.68 \pm 0.23^{*}$ & $1.77 \pm 0.21^{*}$ & $1.50 \pm 0.26^{*}$ & $1.53 \pm 0.17^{*}$ \\
Albumine $(\mathrm{g} / \mathrm{dl})$ & $2.97 \pm 0.22$ & $2.88 \pm 0.28$ & $2.83 \pm 0.20$ & $3.03 \pm 0.22$ & $3.08 \pm 0.22$ & $2.83 \pm 0.19$ \\
Rectal temperature $\left({ }^{\circ} \mathrm{C}\right)$ & $38.70 \pm 0.12$ & $38.48 \pm 0.12^{*}$ & $38.38 \pm 0.07^{*}$ & $38.30 \pm 0.06^{*}$ & $38.35 \pm 0.10^{*}$ & $38.32 \pm 0.07^{*}$ \\
Heart rate $(\mathrm{bpm})$ & $87.50 \pm 4.98$ & $77.00 \pm 4.00^{*}$ & $75.67 \pm 3.50^{*}$ & $75.67 \pm 3.67^{*}$ & $71.00 \pm 2.37^{*}$ & $74.17 \pm 4.62^{*}$ \\
Respiratory rate $(\mathrm{c} / \mathrm{min})$ & $46.83 \pm 4.92$ & $28.67 \pm 2.94^{*}$ & $24.50 \pm 3.27^{* \bullet}$ & $22.67 \pm 2.87^{*}$ & $21.33 \pm 2.50^{*}$ & $20.83 \pm 2.14^{*}$ \\
\hline
\end{tabular}

Significance (Bonferroni - $\mathrm{P}<0,05)$ :

* vs $1^{\text {st }}$ day

- vs $30^{\text {th }}$ day

- vs $60^{\text {th }}$ day

- vs $90^{\text {th }}$ day

$\Delta$ vs $120^{\text {th }}$ day

$\diamond$ vs $1^{\text {st }}, 30^{\text {th }}, 60^{\text {th }}, 90^{\text {th }}$ days

Table 2. Average values of the haematochemical and physiological parameters, expressed in their conventional units of measurement together with the related standard deviations and statistical significance observed in different experimental conditions in six Arabian foals

\begin{tabular}{|c|c|c|c|c|c|c|}
\hline \multirow{2}{*}{ Parameters } & \multicolumn{6}{|c|}{ Experimental conditions } \\
\hline & $1^{\text {st }}$ day & $30^{\text {th }}$ day & $60^{\text {th }}$ day & $90^{\text {th }}$ day & $120^{\text {th }}$ day & $150^{\text {th }}$ day \\
\hline Total protein $(\mathrm{g} / \mathrm{dl})$ & $5.42 \pm 0.39$ & $6.33 \pm 0.22^{*}$ & $6.07 \pm 0.16$ & $6.47 \pm 0.22^{*}$ & $6.72 \pm 0.31^{* \bullet \bullet}$ & $6.22 \pm 0.24^{* \mathbf{\Lambda}}$ \\
\hline Urea $(\mathrm{mg} / \mathrm{dl})$ & $18.85 \pm 0.29$ & $15.12 \pm 0.87^{*}$ & $9.62 \pm 0.63^{* \bullet}$ & $13.15 \pm 0.59^{* \bullet \bullet}$ & $16.58 \pm 0.67^{* \bullet \bullet \bullet}$ & $17.97 \pm 0.77^{\bullet \bullet \bullet \Delta}$ \\
\hline Uric acid (mmol/1) & $0.46 \pm 0.06$ & $0.57 \pm 0.06_{*}^{*}$ & $0.50 \pm 0.06^{\bullet}$ & $0.52 \pm 0.06$ & $0.50 \pm 0.06^{\bullet}$ & $0.51 \pm 0.06$ \\
\hline Creatinine (mg/dl) & $2.72 \pm 0.35$ & $1.30 \pm 0.18^{*}$ & $1.61 \pm 0.23^{* \bullet}$ & $1.62 \pm 0.23^{* \bullet}$ & $1.70 \pm 2.24^{* \bullet}$ & $1.77 \pm 0.22^{* \bullet}$ \\
\hline Albumine $(\mathrm{g} / \mathrm{dl})$ & $3.03 \pm 0.26$ & $2.97 \pm 0.22$ & $2.93 \pm 0.32$ & $3.13 \pm 0.26$ & $3.08 \pm 0.29$ & $3.03 \pm 0.22$ \\
\hline Rectal temperature $\left({ }^{\circ} \mathrm{C}\right)$ & $38.77 \pm 0.14$ & $38.52 \pm 0.15^{*}$ & $38.42 \pm 0.12^{*}$ & $38.35 \pm 0.08^{* \bullet}$ & $38.33 \pm 0.10^{* \bullet}$ & $38.33 \pm 0.10^{* \bullet}$ \\
\hline Heart rate (bpm) & $87.33 \pm 2.94$ & $79.17 \pm 2.32^{*}$ & $78.17 \pm 2.32^{*}$ & $72.67 \pm 3.56^{* \bullet \bullet}$ & $73.67 \pm 4.63^{* \bullet}$ & $74.33 \pm 5.28^{*}$ \\
\hline Respiratory rate (c/min) & $44.33 \pm 4.68$ & $28.83 \pm 2.86^{*}$ & $22.33 \pm 2.73^{* \bullet}$ & $21.33 \pm 1.51^{* \bullet}$ & $21.50 \pm 2.17^{* \bullet}$ & $21.33 \pm 1.03^{* \bullet}$ \\
\hline \multicolumn{7}{|c|}{$\begin{array}{l}\text { Significance (Bonferroni } \mathrm{P}<0,05) \text { : } \\
* \quad \text { vs } 1^{\text {st }} \text { day } \\
\text { - } \quad \text { vs } 30^{\text {th }} \text { day } \\
\text { - vs } 60^{\text {th }} \text { day } \\
\text { vs } 90^{\text {th }} \text { day } \\
\text { A } 120^{\text {th }} \text { day }\end{array}$} \\
\hline
\end{tabular}

Lack of data for foal led to assess the health status of neonatal foals by examining the pattern of some physiological and hematological parameters from birth to fifth month of life. Changes in these variables which occur during the observed period can be explained by growth and differentiation-related processes that are specific for young animals (Waelchli et al., 1992; Brommer et al., 2001). The low concentration of total protein on the day of birth is probably due to the low concentration of globulins at birth (Sato et al., 1978). Statistical significant increase on the $30^{\text {th }}$ day of life, compared to the birth, could be due to the immunological adjustments of the organism. At birth, there are minimal quantities of immunoglobulins (Bauer et al.,
1989), which show a rapid increase after the ingestion of the colostrum (Bauer et al., 1985). As the maternal antibodies decline, due to normal turn-over, the foal rapidly gains immunocompetence and begins to synthesize its own immunoglobulins, reaching normal adult levels (Spensley et al., 1987; Kaneko, 1989). Statistical significant increase of total proteins is supported by previous studies, which show lower values in young animals compared to adults (Rumbaugh and Adamson, 1983; Gill et al., 1985; Bauer et al., 1985). Total proteins pattern is the same in both breeds: this parameter shows a mean value of $5.47 \mathrm{~g} / \mathrm{dl}$ and of $5.42 \mathrm{~g} / \mathrm{dl}$, respectively, in Thoroughbred and Arabian foals on the first day of life and reaches $6.25 \mathrm{~g} / \mathrm{dl}$ in 
Thoroughbred and $6.47 \mathrm{~g} / \mathrm{dl}$ in Arabian foals at the $30^{\text {th }}$ day of life. The contemporary decrease of urea, which falls from the mean value of $18.7 \mathrm{mg} / \mathrm{dl}$ in Thoroughbred and $18.8 \mathrm{mg} / \mathrm{dl}$ in Arabian foals after birth to $12.98 \mathrm{mg} / \mathrm{dl}$ in Thoroughbred and to $13.1 \mathrm{mg} / \mathrm{dl}$ in Arabian foals on the $30^{\text {th }}$ day of life, confirms the growth requirements of the foal, as suggested by the high protein retention/protein intake ratio observed during this period (Doreau et al., 1986). It could be associated with an increased demand for amino acids necessary for structural and enzymatic protein synthesis, according to previous studies (Bauer et al., 1984). The statistical significant decrease of total proteins from the $120^{\text {th }}$ day to the $150^{\text {th }}$ day of life in both breeds has to be related to the contemporary increase of urea, as the main residue of protein metabolism. Uric acid shows a mean value of $0.46 \mathrm{mmol} / 1$ in both Thoroughbred and Arabian foals in the first month of life and reaches $0.50 \mathrm{mmol} / 1$ in Thoroughbred and $0.51 \mathrm{mmol} / 1$ in Arabian foals in the fifth month of life. Most of literature about serum creatinine involvement in muscular metabolism refers to adult horses. Data obtained from researches on foals are scarce and not univocal and can be explained with the metabolic adjustments which occur during growth in young animals. In this study, the same behavior was also observed for both breeds, with a statistical significant decrease $(P<0.05)$, which is in agreement with previous studies (Rose et al., 1979; Harvey et al., 1984; Edwards et al., 1990). It can be related to the rapid growth and muscular development of the foal during the first months of life. In relation to albumine dosage no statistical significant differences were observed in both breeds. The high value of rectal temperature at the birth is supported by literature (Ousey et al., 1991); this parameter follows, in both breeds, the circadian pattern reported for the foal (Piccione et al., 2002).

Heart and respiratory rates show high values in both breeds 1 day after the birth $(87.5 \mathrm{bpm}$ and $46.8 \mathrm{c} / \mathrm{min}$ in Thoroughbred foals and $87.3 \mathrm{bpm}$ and $44.3 \mathrm{c} / \mathrm{min}$ in Arabian foals). This is probably due to an excited or active status of the foal. The foal heart rate immediately after birth is around $40-80 \mathrm{bpm}$, and increases up to $130-150 \mathrm{bpm}$ because of the physical activity due to its first attempts to stand; during the following days, heart rate settles at 70-100bpm (Koterba, 1990). The heart rate pattern recorded on the foal's first week of life depends on cardio-circulatory system modifications that occur within the first 12 hours of life: the foramen ovale and the arterial duct close and the right-left cardiac shunt that persists in approximately $18 \%$ of cases (Bucca, 2001) resolves spontaneously during the following weeks. In the newborn, the heart is forced to pump the blood through a vascular system that presents a strong elastic, peripheral resistance. Since the organism of the newborn is not yet able to vary cardiac output, it compensates the limited systolic volume by increasing the heart rate. This may explain the significant effect of time on the statistically significant decrease $(\mathrm{P} \neq 0.05)$ in heart rate observed in both breeds during the 30 days of life (Piccione et al., 2005).

A significant effect of time was also found in both groups for respiratory rate. It confirms the homeostatic physiological variability of this parameter during the neonatal period. It is known that in newborns there is a physiological respiratory immaturity due to an incomplete anatomical-functional development. Indeed, the physiological values of the respiratory rate are around 60-80 ram immediately after birth (Koterba, 1990), though it significantly drops within 15 minutes (Stewart et al., 1984). Twelve hours later this value is $30-50 \mathrm{c} / \mathrm{min}$ and by the end of the first week of life, it ranges between 20 and 40c/min (Koterba, 1990).

\section{CONCLUSIONS}

It is concluded that hematochemical and physiological parameters of foals are to be considered in relation to age, particularly with differentiation-related processes which accompany the growth of young organisms and should be cautiously interpreted to allow for individual variations.

\section{REFERENCES}

AGUERA, E.I.; RUBIO, M.D.; VIVO, R. et al. Blood parameter and heart rate response to training in Andalusian horses. Rev. Esp. Fisiol., v.51, p.55-64, 1995.

BAUER, J.E.; ASQUITH, R.L.; KIVIPELTO, J. Serum biochemical indicators of liver function in 
neonatal foals. Am. J. Vet. Res., v.50, p.2037-2041, 1989.

BAUER, J.E.; HARVEY, J.W.; ASQUITH, R.L. et al. Clinical chemistry reference values of foals during the first year of life. Equine Vet. J., v.16, p.361-363, 1984.

BAUER, J.E.; HARVEY, J.W.; ASQUITH, R.L. et al. Serum protein reference values in foals during the first year of life: comparison of chemical and electrophoretic methods. Vet. Clin. Pathol., v.14, p.1422, 1985.

BROMMER, H.; SLOET VAN OLDRUITENBORGH-OOSTERBAAN, M.M.; KESSELS, B. Haematological and blood biochemical characteristics of Dutch warmblood foals managed under three different rearing conditions from birth to 5 months of age. Vet. Q., v.23, p.92-95, 2001.

BUCCA, S. Valutazione e gestione del neonato equino a rischio. Riv. Ippiat. Ippol. v. 7, p.7-31, 2001.

CAOLA, G. Valori ematochimici del puledro purosangue inglese durante l'accrescimento. Livelli sierici di creatinina e creatina fosfochinasi. Clin. Vet., v.109, p.444-451, 1986.

CAOLA, G.; BALBO, S.M. Modelli di correlazione tra parametri ematochimici, età e peso corporeo nel cavallo. Atti SISVET, v.XLI, 239-242, 1987.

DOREAU, M.; BOULOT, S.; MARTIN-ROSSET, W. et. al. Relationship between nutrient intake, growth and body composition of the nursing foal. Reprod. Nutr. Develop., v.26, p.683-690, 1986.

EDWARDS, D.J.; BROWNLOW, M.A.; HUTCHINS, D.R. Indices of renal function: values in eight normal foals from birth to 56 days. Aust. Vet. J., v.67, p.251254, 1990.

EVANS, D.L.; PRIDDLE, T.L.; DAVIE, A.J.; Plasma lactate and uric acid responses to racing in pacing Standardbreds and relationships with performance. Equine Vet. J., v.34, suppl., p.131-134, 2002.

GILL, J.; JAKUBOW, K.; KOMPANOWSKAJEZIERSKA, E. et al. Seasonal changes in blood serum protein fractions and in activity of AspAT and AlAT in Arabian brood mares and their foals. Comp. Biochem. Physiol., v.82A, p. 167-178, 1985.

GREPPI, G.F.; SERRANTONI, M. Diagnostica chimico-clinica e profilo metabolico nel cavallo. Summa, v.10, p.53-59, 1993.

HARVEY, J.W.; ASQUITH, R.L.; McNULTY, P.K. et al. Hematology of foals up to one year old. Equine Vet. J., v.16, p.347-353, 1984.

JEFFCOTT, L.B.; ROSSDALE, P.D.; LEADON, D.P. Haematological changes in the neonatal period of normal and induced premature foals. J. Reprod. Fertil., v.32, p.537-544, 1982.
JUDSON, G.J.; MOONEY, G.J.; THORNBURY, R.S. Plasma biochemical values in Thoroughbred horses in training. In: SNOW, D.H.; PERSSON S.G.B.; ROSE, R.J. (EDS) Equine exercise physiology, Cambridge: Granta Editions, 1983. p.354-360.

KANEKO, J.J. Serum proteins and the dysproteinemias. In: KANEKO, J.J. (Ed.). Clinical biochemistry of domestic animals. 4.ed. California: Academic, 1989. p.146.

KOTERBA, A.M. Physical examination. In: KOTERBA, A.M.; DRUMMOND, W.H.; KOSCH, P.C. (Eds.). Equine clinical neonatology. USA: Lea \& Febiger, 1990. p.74-75.

MARTIN-ROSSET, W.; BOCCARD, R.; JUSSIAUX, $M$. et al. Croissance relative des différentes tissus, organes et régions corporelles entre 12 et 30 mois chel le cheval de boucherie de différentes races lourdes. Ann. Zootech., v.32, p.153-174, 1983.

OUSEY, J.C.; McARTHUR, A.J.; ROSSDALE, P.D. Metabolic changes in thoroughbred and pony foals during the first $24 \mathrm{~h}$ post partum. J. Reprod. Fertil., v.44, suppl., p.561-570, 1991.

PICCIONE, G.; ASSENZA, A., COSTA, A. et al. monitoring of some physiological parameters during the first 30 days of a foal's life. Med. Weter., v.61, p.1142-1144, 2005.

PICCIONE, G.; CAOLA, G.; REFINETTI, R. Maturation of the daily body temperature rhythm in sheep and horse. J. Thermal Biol., v.27, p.333-336, 2002.

ROSE, R.J.; BACKHOUSE, W.; CHAN, W. Plasma biochemistry changes in Thoroughbred foals during the first 4 weeks of life. J. Reprod. Fertil., v.27, suppl., p.601-605, 1979.

RUMBAUGH, G.E.; ADAMSON, P.J. Automated serum chemical analysis in the foal. J. Am. Vet. Med. Assoc., v.183, p.769-772, 1983.

SATO, T.; ODA, K.; KUBO, M. Hematological and biochemical values of Thoroughbred foals in the first six months of life. Cornell Vet., v.69, p.3-19, 1978.

SPENSLEY, M.S.; CARLSON G.P.; HARROLD, D. Plasma, red blood cell, total blood and extra cellular fluid volumes in healthy horse foals during growth. Am. J. Vet. Res., v.48, p.1703-1707, 1987.

STEWART, J.H.; ROSE, R.J.; BARKO, A.M. Respiratory studies in foals from birth to seven days old. Equine Vet. J., v.16, p. 323-328, 1984.

WAELCHLI, R.O;; LUTZ, H.; HERMANN, M. Clinico-chemical blood parameters in foals in the first two months of life. Schweiz. Arch. Tierheilkd., v.134, p.471-482, 1992. 